\title{
NUTRITIVE VALUE OF ELRASHAD (Lepidium sativum L.) SEEDS GROWN IN SAUDI ARABIA
}

\author{
Ghedeir M Alshammari ${ }^{*}$, Mohammed A Yahya, Saifeldein B Ahmed
}

Department of Food Science \& Nutrition, College of Food and Agricultural Sciences, King Saud University; Riyadh, 11451, P.O. Box 2460,Saudi Arabia.

Received - March 29, 2017; Revision - April 18, 2017; Accepted - April 22, 2017

Available Online - August 31, 2017

DOI: http://dx.doi.org/10.18006/2017.5(Spl-1-SAFSAW).S155.S159

KEYWORDS
Lepidium sativum,
Elrashad seeds
minerals
fatty acids
amino acids

* Corresponding author

E-mail: aghedeir@ksu.edu.sa (Ghedeir Muslem Alshammari)

Peer review under responsibility of Journal of Experimental Biology and Agricultural Sciences.

Production and Hosting by Horizon Publisher India [HPI] (http://www.horizonpublisherindia.in/).

All rights reserved.

\begin{abstract}
Elrashad (Lepidium sativum L.) is a perennial plant that is cultivated in some regions of Saudi Arabia where the seeds are used for therapeutic and dietary purposes. The aim of this study was to obtain Elrashad seeds (Saudi cultivar) flour and analyse the flour for proximate, minerals, fatty acids, and amino acids compositions. The results of study showed that Elrashad seeds contain high levels of protein $(20.84 \%)$, fat $(23.83 \%)$, and crude fibre $(7.15 \%)$, on a dry weight basis. This study showed that Elrashad seeds may be considered as a good source of essential minerals, such as potassium, phosphorus, calcium, and iron. The fatty acid analysis showed that Elrashad seed oil contains high levels of unsaturated fatty acids (82.15\%) such as the essential fatty acid linoleic acid (11.25\%), and linolenic acid $(30.07 \%)$. Further, results also revealed that Elrashad seed protein has fair amounts of essential amino acids, and the limiting amino acids are methionine and cysteine. These results may highlight the potential of Elrashad seeds as a source of chemical constituents that may be considered for human nutrition. Further studies are needed to investigate other nutritional aspects of Elrashad seeds.
\end{abstract}

All the article published by Journal of Experimental Biology and Agricultural Sciences is licensed under a Creative Commons Attribution-NonCommercial 4.0 International License Based on a work at www.jebas.org. 


\section{Introduction}

Lepidium sativum (L.) commonly known as garden cress is perennial edible herb that belongs to the family Cruciferae, and widely cultivated in temperate climates throughout the world (Adam, 1999). It is grown in many parts of Saudi Arabia, such as in North of El-hegaz, east of Naged and in the Eastern region. Elrashad (as locally known) plant is grown mainly for its seeds in Saudi Arabia (Al-Jassas \& Al-Jasser, 2012). Elrashad seeds are used in traditional medicine to treat asthma, hypertension, hepatotoxicity and hyperglycaemia (Gokavi et al., 2004; Ghante et al., 2011; Behrouzian et al., 2014). Further, Mathews et al. (1993) reported that L. sativum seeds, known in India as Haliv, have traditionally been used in the diet of lactating women and are used for the treatment of diarrhoea and dysentery. The chemical composition of garden cress seeds (Indian cultivar) was investigated by Gokavi et al. (2004). They also explored the possibility of using the seeds as a nutraceutical food ingredient. $L$. sativum seeds contains $18-24 \%$ fat and $30 \%$ of the total fatty acids are alpha linolenic acid and the seed oil contains the essential alpha linoleic acid (Diwakar et al., 2008). The primary fatty acids in $L$. sativum oil are oleic (30.6 wt \%) and linolenic acids (29.3 wt $\%$ ), and the oil has been found to contain high concentrations of tocopherols. It also contains reasonable amounts of lignans, antioxidants, and the primary phytosterols such as sitosterol and campesterol (Bryan et al., 2009; Shail et al., 2016). L. sativum can be considered as under-utilized crop, and there have been very few reports in Saudi Arabia regarding the chemical composition of the seeds. However, Adam (1999) reported on the toxicological effects of $L$. sativum seeds incorporation into the diets of rats. Therefore, the aim of this study was to elucidate the proximate, mineral, fatty acid and amino acid compositions of Elrashad seeds from plants grown in Saudi Arabia.

\section{Materials and Methods}

\subsection{Materials}

Elrashad seeds were obtained from a local market in Riyadh city. The seeds were originally produced from a Saudi cultivar grown in the northen region of Al-hegaz. All chemicals used were of analytical grade.

\subsection{Methods}

After cleaning, the seeds were ground into a fine powder using a coffee miller and then sieved to pass through a $425 \mu \mathrm{m}$ (USA standard sieve) mesh. The resultant flour was kept at $4^{\circ} \mathrm{C}$ for further analysis.

\subsubsection{Proximate composition}

The Elrashad seed flour was analysed by standard methods 934.01.988.05.920.39, 942.05 and 962.09 for moisture, protein
(NX6-25) fat, ash and crude fibre, respectively (AOAC, 2000).

\subsubsection{Mineral analysis}

Wet digestion method (AOAC, 2000) was performed prior to mineral contents determination in Elrashad seed flour. Total phosphorus was determined in the digested solution according to Taussky \& Shorr (1993), and K, Ca, Na, Fe, Zn and Cu were determined using an atomic absorption spectrophotometer (Perkin-Elmer Instrument model 2380).

\subsubsection{Fatty acid analysis}

Oil from the whole flour of Elrashad seeds was extracted by shaking in n-hexane for two hours (solvent: flour ratio was 10:1). After filtration, the oil was desolventised using a rotary evaporator under vacuum. The oil was saponified with ethanolic potassium hydroxide and fatty acid methyl esters were formed by a reaction with borontriflouride methanol (Andersson et al., 1999). A Perkin-Elmer gas chromatograph (Model F 22) with a flame ionization detector at $250^{\circ} \mathrm{C}$ was used for fatty acid quantification with nitrogen as the carrier gas. A glass column $(2 \mathrm{~m} \times 2.5 \mathrm{~mm})$ packed with chrom Q 80/100 at a temperature of $240^{\circ} \mathrm{C}$ was used for the analysis and standard fatty acid methyl esters (Sigma Chemical Co. St. Louis, Mo, USA) were used for identification. The area under each peak was measured and the fatty acid percentages were expressed in terms of the total area.

\subsubsection{Amino acid analysis}

Samples containing $10 \mathrm{mg}$ protein were hydrolysed for $24 \mathrm{~h}$ under vacuum at $110^{\circ} \mathrm{C}$ using $6.0 \mathrm{~N} \mathrm{HCl}$. Cysteine levels were determined by subjecting the samples to performic acid oxidation prior to acid hydrolysis. The amino acid analysis was performed on a reverse phase-high pressure liquid chromatography (Shimadzu LC-LOAD, Shimadzu Corporation, Kyoto, Japan). The samples were analysed on a shimpack amino-Na type column $(10 \mathrm{~cm} \times 6.0 \mathrm{~mm})$ obtained from the Shimadzu Corporation. The post column samples were derivatised with $O$-phthaldialdehyde (OPA) and the data were integrated using Integrator Model CR7A (Shimadzu chromatopac data processor). Amino acid scores were calculated using the FAO/WHO/UNU (1985) reference protein and the following formula:

$$
\text { Amino acid score }=\frac{\text { gram essential amino acid per } 100 \mathrm{~g} \text { test protein }}{\text { gram essential amino acid per } 100 \mathrm{~g} \text { reference protein }}
$$

\subsubsection{Statistical analysis}

The means and standard deviations of the results from the three replicates were determined by SAS Program software (SAS 9.2, 2015). 


\section{Results and Discussion}

\subsection{Chemical composition}

The proximate composition of Elrashad seeds is shown in Table 1. The major component in Elrashad seeds was carbohydrate followed by oil and protein. These results differ slightly from those reported by Gokavi et al. (2004) for carbohydrates $(41.25 \%)$, oil $(27.48 \%)$ and protein $(22.4 \%)$; but these values were close to the values reported by Zia-Ul-Haq et al. (2012), who found that the carbohydrate contents were $37.60 \pm 0.89 \%$ to 32.87 $\pm 0.29 \%$ and the protein contents were $23.36 \pm 1.02 \%$ to 24.18 $\pm 1.54 \%$ in garden cress seeds on a dry weight basis. The differences may be due to the use of different varieties, variations in agronomic practices, climatic and geographical conditions of the area from where the seeds were collected (Zia-Ul-Haq et al., 2011; Ahmed et al., 2013).

Table 1 Chemical composition of the whole seed flour

\begin{tabular}{|cc|}
\hline Nutrients & (Fresh weight basis) \\
\hline \multirow{2}{*}{ Moisture } & $4.89 \pm 0.050$ \\
\hline \multirow{2}{*}{ Protein } & $19.82 \pm 0.205$ \\
& $(20.84)^{*}$ \\
\hline \multirow{2}{*}{ Oil } & $22.66 \pm 0.007$ \\
& $(23.83)^{*}$ \\
\hline \multirow{2}{*}{ Ash } & $5.83 \pm 0.389$ \\
& $(6.13)^{*}$ \\
\hline \multirow{2}{*}{ Crude fibre } & $\begin{array}{c}\text { Mean } \\
\text { Carbohydrates }\end{array}$ \\
\hline \multirow{2}{*}{ (7.15)* } \\
\hline
\end{tabular}

Data are average of three replicates; \pm followed by the standard deviation (\%); * Protein, oil, ash, crude fibre and carbohydrates values between brackets are calculated on dry weight basis

\subsection{Mineral composition}

The mineral analysis results are shown in Table 2. Seven elements that are considered essential for human health were investigated. Potassium had the highest content in Elrashad seeds followed by phosphorus, calcium and iron (Table 2). Gopalan et al. (2000) also reported that $377 \mathrm{mg}$ calcium, $723 \mathrm{mg}$ phosphorus and $100 \mathrm{mg}$ iron per $100 \mathrm{~g}$ sample were present in L. sativum seeds, and Gokavi et al. (2004) reported $1193.95 \mathrm{mg} / 100 \mathrm{~g}$ potassium in $L$. sativum seeds. Furthermore, these results were close to the value mentioned by Jain et al. (2016) for calcium and zinc (360.50 mg and $5.21 \mathrm{mg} / 100 \mathrm{~g}$, respectively). The differences between the reported values for the Indian cultivars and the values obtained in this study (for the Saudi cultivar) could be due to varietal and locational differences. Elrashad seeds may contribute significantly to the overall dietary intake of these elements based on the recommended daily intake (Cuthbertson, 1989) and on the results the of mineral composition in this study.
Table 2 Mineral composition of Elrashad seeds (mg/100gram)

\begin{tabular}{|cc|}
\hline Minerals & Mean \\
\hline Potassium (k) & $785.0 \pm 7.51$ \\
\hline Phosphorus (p) & $616.50 \pm 9.67$ \\
\hline Calcium (ca) & $253.0 \pm 1.04$ \\
\hline Sodium (na) & $40.50 \pm 0.05$ \\
\hline Iron (fe) & $53.81 \pm 0.04$ \\
\hline Copper (cu) & $1.90 \pm 0.09$ \\
\hline Zinc (zn) & $4.10 \pm 0.07$ \\
\hline
\end{tabular}

Data are average of three replicates; \pm followed by the standard deviation (\%);

\subsection{Fatty acid composition}

The fatty acid profile (Table 3) showed that the major saturated fatty acid in Elrashad seeds oil were palmitic acid followed by arachidic and stearic acid. Oleic acid (24.49\%) and eicosenoic acid $(12.60 \%)$ were the major mono-unsaturated fatty acids. While the contents of linoleic acid and linolenic acid, were $11.25 \%$ and $30.07 \%$, respectively. Bhakare et al. (1993) reported that linolenic acid $(33.8 \%)$ was the major fatty acid in L. sativum seed oil. The unsaturated fatty acids represented $82 \%$ of the total fatty acid content in Elrashad seed oil (Table 3), Al-Jassir et al. (1995) reported that the unsaturated fatty acids in Saudi Samh seed oil represents more than $81 \%$ of the total fatty acid content. El-adawy \& Taha (2001) found that oil samples from different sources had high levels of total unsaturated fatty acids. These were $78.35 \%$ for watermelon seed kernel oil, $76.46 \%$ for pumpkin kernels and $82.45 \%$ for paprika seed oil. The fatty acid composition of the Elrashad seeds analysed in this study agrees with the results reported by Al-Jassas \& Al-Jasser (2012) and Jain et al. (2016).

Table 3 Fatty acid composition of Elrashad seeds oil

\begin{tabular}{|c|c|}
\hline Fatty acid & Percentage \\
\hline Myristic & 1.50 \\
\hline Palmitic & 8.80 \\
\hline Stearic & 3.49 \\
\hline Oleic & 23.49 \\
\hline Linoleic & 11.35 \\
\hline Linolenic & 30.07 \\
\hline Arachidic & 4.06 \\
\hline Eicosenoic & 12.60 \\
\hline Erucic & 4.64 \\
\hline Saturated fatty acids & 17.85 \\
\hline Unsaturated fatty acid & 82.15 \\
\hline
\end{tabular}


Table 4 Amino acid composition and scores for Elrashad seeds

\begin{tabular}{|c|c|c|c|}
\hline Essential amino acids & Amino acid* composition ( $\mathrm{g} / 100 \mathrm{~g}$ protein) & Amino acid score & Reference** protein ( $\mathrm{g} / 100 \mathrm{~g}$ protein) \\
\hline Lysine & $2.26 \pm 0.390$ & 0.91 & 5.8 \\
\hline Threonine & $5.39 \pm 0.014$ & 1.58 & 3.4 \\
\hline Valine & $6.24 \pm 0.007$ & 1.78 & 3.5 \\
\hline Methionine & $1.06 \pm 0.000$ & & \\
\hline Cysteine & 0.80 & & \\
\hline Methionine + Cysteine & 1.86 & $0.74 * * *$ & 2.5 \\
\hline Isoleucine & $5.21 \pm 0.014$ & 1.86 & 2.8 \\
\hline Leucine & $9.03 \pm 0.007$ & 1.37 & 6.6 \\
\hline Phenylalanine & $5.80 \pm 0.004$ & & \\
\hline Tyrosine & $3.82 \pm 0.000$ & & \\
\hline Phenylalanine + Tyrosine & 9.62 & 1.53 & 6.3 \\
\hline Histidine & $3.51 \pm 0.007$ & 1.85 & 1.9 \\
\hline \multicolumn{4}{|l|}{ Non-essential amino acids } \\
\hline Arginine & $2.89 \pm 0.000$ & & \\
\hline Aspartic acid & $11.47 \pm 0.014$ & & \\
\hline Glutamic acid & $19.68 \pm 0.028$ & & \\
\hline Glycine & $6.49 \pm 0.014$ & & \\
\hline Alanine & $5.85 \pm 0.007$ & & \\
\hline Serine & $5.30 \pm 0.007$ & & \\
\hline
\end{tabular}

*Mean \pm standard deviation, **FAO/WHO/UNU (1985) ***First limiting amino acid

\subsection{Amino acid composition}

Table 4 shows the amino acid composition of Elrashad seeds. The results indicated that glutamic (19.68\%) and aspartic acids (11.74\%) were the most abundant amino acids, followed by leucine and valine. All essential amino acids in the protein found in Elrashad seeds had high amino acid scores, except for lysine and sulphur-containing amino acids where levels were relatively low. However, these results showed that Elrashad seeds contained reasonable levels of most essential amino acids. The results of this study were comparable to the results produced by previous studies on amino acid composition of L. sativum (Gokavi et al., 2004; Zia-Ul-Haq et al., 2011). Young \& Pellet (1994) concluded that the essential amino acid levels found in plant proteins deserve further consideration. For human nutrition adequate quantities of lysine, methionine and tryptophan are critical in foods (FAO/WHO, 1991; Sujak et al., 2006). However, Elrashad seeds, when used as protein source in food formulations, require supplementation with complementary proteins (e.g legumes) to compensate for the deficiency in sulphur-containing amino acids in Elrashad seeds.

\section{Conclusion}

This study showed that Elrashad seeds are a good source of many nutrients, such as proteins, minerals, fibre and essential fatty acids. Elrashad seeds are already locally known and consumed by Saudi people for medicinal and dietary purposes. However, further research studies are needed to explore the nutritional, functional, toxicological and other characteristics of Elrashad seeds and their use in food applications.

\section{Acknowledgement}

The author gratefully thanks to Deanship of Scientific Research, College of Food and Agricultural Sciences, Research Centre, King Saud University, for financial support of this study.

\section{Conflict of interest}

Authors would hereby like to declare that there is no conflict of interests that could possibly arise.

\section{References}

Adam SEI (1999) Effect of various levels of dietary Lepidium sativum L. seeds in rats. American Journal of Chinese Medicine $27: 397-405$.

Ahmed M, Gaafar AAM, Heba EE (2013) Chemical, nutritional and biochemical studies of garden cress protein isolate. Nature \& Science 11: 8 - 13 .

Al-Jassas FM, Al-Jasser MS (2012) Chemical composition and fatty acid content of some spices and herbs under Saudi Arabia conditions. The Scientific World Journal Article ID 859892 doi:10.1100/2012/859892.

Al-Jassir MS, Mustafa AI, Nawawy MA (1995) Studies on samh seeds (Mesembryanthemum forsskglei Hochst) growing in Saudi Arabia 2: chemical composition and microflora of samh seeds. Plant Food for Human Nutrition 48: 185-192.

Anderson AAM, Marker A, Nilsson P, Sorensen H, Amon P (1999) Chemical composition of the potential new oil seed crops, Barbarea vulgaris, Barbarea verna and Lepidium compestre. Journal of the Science of Food and Agriculture 79: 179-186. 
Association of Official Analytical Chemists (AOAC) (2000) Official methods of analysis of AOAC International. Arlington VA, USA, AOAC International.

Behrouzian F, Razavi SMA, Karazhiyan H (2014) Intrinsic viscosity of cress (Lepidium sativum) seed gum: Effect of salts and sugars. Food Hydrocolloids 25: 100-105.

Bhakare HA, Kulakami AS, Khotpol RR (1993) Lipid composition of some seeds of Central India. Journal of Food Science and Technology 30: 54-55.

Bryan RM, Shailesh NS, Jill KW, Steven FV, Roque LE (2009) Composition and physical properties of cress (Lepidium sativum L.) and field pennycress (Thlaspi arvense L.) oils. Industrial Crops and Products 30: 199-205.

Cuthbertson WF (1989) What is a healthy food? Food Chemistry 33: $53-80$

Diwakar BT, Dutta PK, Lokesh BR, Naidu KA (2008) Bioavailability and metabolism of n-3 fatty acid rich garden cress (Lepidium sativum) seed oil in albino rats. Prostaglandins, Leukotrienes \& Essential Fatty Acids 78: 123-130.

El-Adawy TA, Taha KM (2001) Characteristics and composition of watermelon, pumpkin and paprika seed oils and flours. Journal of Agricultural and Food Chemistry 49: 1253-1259.

FAO/WHO (1991) Protein quality evaluation. Report of a joint FAO-WHO Expert Consultation. FAO, Food and Nutrition, 51, Rome, Italy.

FAO/WHO/UNU (1985) Energy and protein requirements. Technical report series No. 724. WHO: Geneva.

Ghante MH, Badole SL, Bodhankar SL (2011) Health benefits of garden cress (Lepidiumsativum Linn.). In: Preedy VR, Watson RR, Patel VB (Eds.) Nuts and seeds in health and disease prevention, Pp. 521-527.

Gokavi SS, Malleshi NG, Guo M (2004) Chemical composition of garden cress (Lepidium sativum) seeds and its fractions and use of bran as a functional ingredient. Plant foods for Human Nutrition 59: 105-11.
Gopalan C, Rama Sastri BV, Balasubramanion SC (2000) nutritive value of Indian foods. National Institute of Nutrition, Indian Council of Medical Research, Hyderabad, India.

Jain T, Grover K, Kaur G (2016) Effect of processing on nutrients and fatty acid composition of garden cress (Lepidium sativum) seeds. Food Chemistry $213: 806-812$

Mathews S, Singhal RS, Kulkarni PR (1993) Some physicochemical characteristics of Lepidium sativum (haliv) seeds. Journal of Biological Chemistry 202: 675-682.

SAS (2015) SAS and all other SAS Institute Inc. product or service names are registered trademarks or trademarks of SAS Institute Inc. in the USA and other countries. ${ }^{\circledR}$ indicates USA registration.

Shail DM, Kumar N, Gupta LN (2016) Nutritional importance of Lepidium sativum L. (Garden cress/Chandrashoor): A Review. International Journal of Pharmacy and Analytical Research 5 : $152-160$.

Sujak A, Kotlarz A, Strobel W (2006) Compositional and nutritional evaluation of several lupin seeds. Food Chemistry 98: 711-719.

Taussky HH, Shorr EA (1993) Amicrocolorimetric method for the determination of inorganic phosphorus. Journal of Biological Chemistry 202: 675-682.

Young VR, Pellet PL (1994) Plant proteins in relation to human protein and amino acid nutrition. American Journal of Clinical Nutrition 59 (Suppl): 12035-12125.

Zia-Ul-Haq M, Ahmad S, Calani L, Mazzeo T, Rio DD, Pellegrini N, Feo VD (2012) Compositional study and antioxidant potential of Ipomoea hederacea Jacq. and Lepidium sativum L. seeds. Molecules 17: 10306-10321.

Zia-Ul-Haq M, Ahmad S, Shad MA, Iqbal S, Qayum M, Ahmad A, Luthria DL, Amarowicz R (2011) Compositional studies of some of lentil cultivars commonly consumed in Pakistan. Pakistan Journal of Botany 43: 1563-1567. 